\title{
Scientific evidence of dockworker illness to nursing clinical reasoning*
}

\author{
Evidências científicas de adoecimento do trabalhador portuário \\ para o raciocínio clínico da enfermagem \\ Evidencias científicas de enfermización del trabajador portuario \\ para el razonamiento clínico de la enfermería
}

\author{
Marlise Capa Verde de Almeida ${ }^{1}$, Marta Regina Cezar-Vaz ${ }^{1}$
}

\section{How to cite this article:}

Almeida MCV, Cezar-Vaz MR. Scientific evidence of dockworker illness to nursing clinical reasoning. Rev Esc Enferm USP. 2016;50(2):341-349. DOI: http:// dx.doi.org/10.1590/S0080-623420160000200022

* Extracted from the thesis "Adoecimento osteomuscular de trabalhadores portuários avulsos e o processamento do raciocínio clínico da enfermagem", Programa de Pós-Graduação em Enfermagem, Universidade Federal do Rio Grande, 2015 .

${ }^{1}$ Universidade Federal do Rio Grande, Escola de Enfermagem, Rio Grande, RS, Brazil.

\begin{abstract}
Objective: To identify scientific evidence of occupational illness of dockworkers published in the literature. Method: systematic review of the literature, developed according to the Cochrane method. The databases searched were: Cochrane, LILACS, MEDLINE/ PubMed, CINAHL and SciELO. Studies from 1988 to 2014 were selected. The data were analyzed according to the level of evidence and Strengthening the Reporting of Observational Studies in Epidemiology. Results: We included 14 studies, in which 11 $(78.6 \%)$ were from international journals. The year of 2012 showed greater number of studies. All studies were classified as: Level of Evidence 4, highlighting lung cancer, musculoskeletal and ischemic diseases, causal link in chemical risks. Conclusion: The development of preventive measures should especially include chemical exposure of workers applying the clinical reasoning of nurses' environmental knowledge to care for illnesses.
\end{abstract}

\section{DESCRIPTORS}

Occupational Health; Occupational Risks; Occupational Health Nursing; Review. 


\section{INTRODUCTION}

Nursing clinical reasoning (CR) comprises cognitive processes used in the collection and processing of information on the health of the individual cared, from which hypotheses can be generated and assessed to meet the needs presented ${ }^{(1)}$. In occupational health, the occupational anamnesis is seen as one of the main tools of obtaining this information, encompassing social and environmental conditions and those related to the organization and development of the work. However, there is also the possibility of obtaining health information through technical and scientific literature, identifying exposure to risk factors at work and the possible illness. Thus, CR guide professionals to define what social and environmental conditions contribute to the determination of the illness, developing, therefore, the causal link, understood as occupational, individual and collective risk factors that lead to occupational illness ${ }^{(2)}$.

In the port working environment context in the southern of Brazil, health research identified the prevalence of some diagnosed illnesses as musculoskeletal disorders ${ }^{(3)}$, hypertension, low-back pain, lung disease and depressive episodes ${ }^{(4-5)}$, additionally, self-reported illnesses such as osteoarticular and mental disorders ${ }^{(6)}$. These results indicate the need to identify whether all port realities lead to the same occupational illnesses, and how nursing can use these and other information in the $\mathrm{CR}$ processing, in order to mitigate and prevent them.

In Brazil, port activities are regulated by Article 40 of Law $12,815 / 2013^{(7)}$ in six categories of workers: Wharfage, stevedoring, freight conference, cargo repair, surveillance of ships and cargo. These services are responsible for the movement of goods within the organized ports, in a manual and automated manner through lifting, conference, storage, among other actions performed on board the ships or in land, in the port docks, warehouses and silos ${ }^{(7)}$. These professional actions work as social and environmental constraints related to work organization and present difficulties of establishing causal links since the jobs analyzed and the responsibilities of each professional category are different. This exposes workers to different occupational risks, continuously and sometimes intermittently, given the rotational shiftwork, modifying the teams and their work actions for each port operation according to demand, which submit the worker to different conditions.

In order to identify the risks and illnesses that affect dockworkers, this systematic review presented, as a general objective, the identification of scientific evidence of occupational illness of dockworkers published in the scientific literature, and as specific objectives, the identification of dockworker illnesses published in the literature and to present the risks that indicate causal link to the illness of dockworkers.

\section{METHOD}

This is a systematic review of the literature, which is a secondary study that supports the development of clinical guidelines, providing information for decision-making and contributing to the development of plans for interventions/ clinical research. This review followed the steps recommend by the Cochrane Handbook $^{(8)}$ : formulation of the research question; location and selection of studies; critical appraisal of studies; data extraction; analysis, presentation and interpretation of data; and improvement and update of the review.

To determine the research question, we used the PICO strategy, which is an illustrative acronym of four essential elements so that the research question support the bibliographic search: Patient, Intervention, Comparison and Outcome ${ }^{(9)}$. In addition, we determined as Boolean operator (delimiter) AND. Thus, the study questions were: What illnesses affect dockworkers? What are the risks that indicate causal link to the illness of dockworkers, according to the scientific literature?

For location and selection of studies, electronic searches were conducted in the following databases: Cochrane Library; Latin American and Caribbean Health Sciences (LILACS), Medical Literature Analysis and Retrieval System Online (MEDLINE/PubMed), Cumulative Index to Nursing and Allied Health Literature (CINAHL) and Scientific Electronic Library Online (SciELO). The searches in the databases were not restricted to a health area and encompassed all areas of knowledge, without specification. The selected publication period was from 1988 to 2014, justified by the establishment year of the Dock Regulations $1988^{(10)}$, with regard to international regulation of health, safety and welfare of port operations workers. Data collection was carried out between January and August 2014, using the following strategies: "portuário"; "dockworker”; "dockworkers", "dock" "and" "worker" and "dock" "and" "workers". Databases that was indexed most of the studies were MEDLINE/ PubMed ( $\mathrm{n}=97 ; 40.6 \%)$ and SciELO ( $\mathrm{n}=71 ; 29.7 \%)$.

Scientific productions were selected as shown in Figure 1.

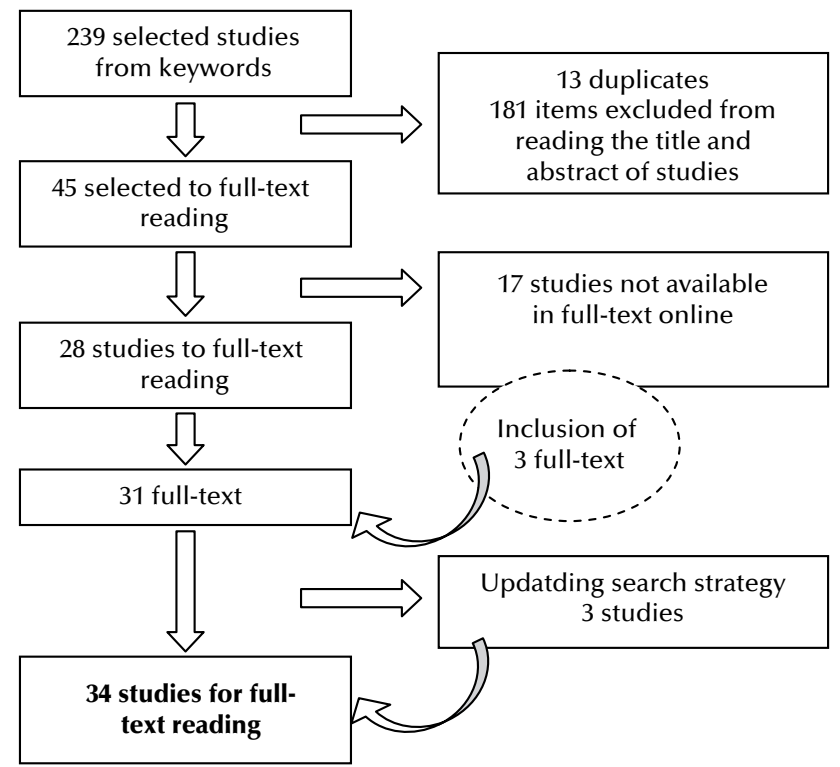

Figure 1 - Flowchart distribution and selection of studies - Rio Grande, RS, Brazil, 2015.

A total of 13 studies were excluded since they were duplicates in the databases. After analytical reading of the title and abstract, 45 studies were selected to full-text reading. Of these, 17 (37.8\%) were not available online, thus, the full versions were requested to the authors, which allowed the inclusion of 
three full studies. From this selection, we obtained 31 studies to full-text reading and after search update, held in September 2014, three more studies were included, totaling 34 studies.

The inclusion criteria were: studies indexed in full in the databases listed and available online; meeting the objectives of the investigation; publication in the period between 1988 and 2014; abstract presentation for screening in Portuguese, English and Spanish. A protocol of analysis and synthesis of the studies was used, comprising aspects of study type, year of publication, number of dockworkers, type of illness and scientific level of evidence assessed in the studies.

The analysis and interpretation of the data were carried out from the seven Evidence levels determined by the Rating System for the Hierarchy of Evidence ${ }^{(11)}$, to quantify and qualify the evidence from studies that identified illnesses that affected dockworkers. The studies were further classified according to the STROBE scale, which contains 22 items with recommendations to assess the adequacy of the description of all the steps of the observational studies. Each criterion received a score of zero to one, which was subsequently converted into a percentage, considering good quality studies the percentage higher than $40 \%$.

Thus, for the study of illnesses related to port work, we expanded the view at the occupational risks and their causal links, building three categories of analysis: Scientific evidence of the illnesses that affect dockworkers; The illnesses related to dockworkers and Risks that indicate causal link with illnesses that affected dockworkers.

In order to respect ethical issues and authorship requirements, the studies cited will be properly referenced throughout this study, according to Law No. 9,610, of February 19, $1998^{(12)}$, which reports Author's Copyright.

\section{RESULTS}

The search resulted in 239 studies, selected from the established inclusion criteria. The use of the term "dock" resulted in a greater number of publications, indicating an efficient search term, although not belonging to the Descriptors in Health Sciences (DeCS) or the Medical Subject Headings (MESH). From the application of the inclusion and exclusion criteria and from the level of evidence classification and STROBE scale, 14 studies were obtained, of which 11 (78.6\%) were published in English and three (21.4\%) in Portuguese.

Of the 11 studies published in English, one (7.1\%) was conducted in Brazil, while all the studies published in Portuguese were developed in the country. Within the 25 years search period, 15 studies did not publish scientific studies on the topic (Figure 2). Regarding the journals where the studies were published, 11 studies (78.6\%) were published in international journals, highlighting the Environmental Health Perspectives and the Occupational and Environmental Medicine. Three studies were published in national journals, two of the Nursing area: Acta Paulista de Enfermagem and Revista Latino-Americana de Enfermagem; the third was published in Cadernos de Saúde Coletiva, from Rio de Janeiro.

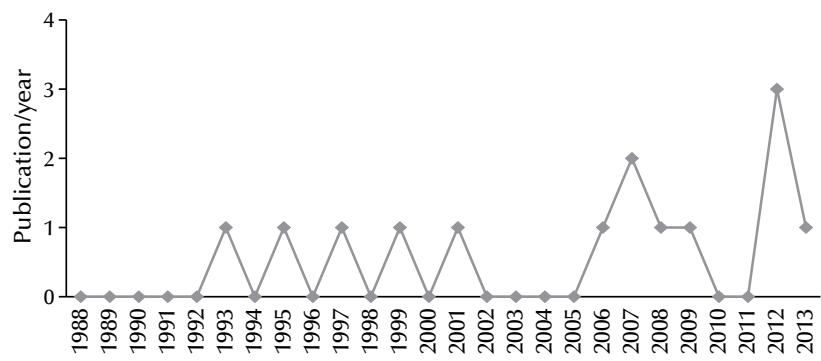

Figure 2 - Number of publications/per year considering the study period - Rio Grande, RS, Brazil, 2015.

We highlight, among international journals, in addition to those already cited, those focusing on environmental issues such as the Indian Journal Occupational Environmental Medicine, the International Archives Occupational Environmental Health, the Scandinavian Journal of Work, and the Environment \& Health. Regarding the indexing of studies, we observed an expressive variability of the descriptors used, especially "lung cancer" $(n=4)$, "cumulative trauma disorder" ( $\mathrm{n}=1)$ "ischemic heart disease" $(\mathrm{n}=1)$ and "mesothelioma" ( $n=3)$. In order to represent the risks, we highlight "asbestos" ( $n=3)$, "diesel exhaust" $(n=3)$; “occupational exposure" $(n=3)$.

The number of dockworkers investigated in the studies ranged from 13 to 12,652 individuals, highlighting that in six studies, the worker's health was indirectly investigated, using secondary data (databases and medical records).

\section{SCIIENTIFIC EVIDENCE OF THE ILLNESSES THAT AFFECT DOCKWORKERS}

The first category of analysis aimed at identifying the level of evidence of scientific studies, highlighting the preferred inclusion of randomized controlled trials, once they allow a more clear identification of the effects of clinical actions in health ${ }^{(8)}$. However, the search did not result in studies with this methodological design, therefore, nonrandomized studies that identified scientific evidence covering the health of dockworkers and highlighting the gaps in health surveillance of these workers were included. Thus, a total of 14 studies, all of Evidence Level 4 - cohort and case-control studies.

The illnesses and risks identified in the studies are presented in Table 1.

Table 1 - Characterization of studies by the title, year of publication, country, design/number of participants, type of illness and risk, ordered by decreasing magnitude as quality score (STROBE) - Rio Grande, RS, Brazil, 2015.

\begin{tabular}{|c|c|c|c|c|}
\hline Title or references & $\begin{array}{l}\text { Year/ } \\
\text { country }\end{array}$ & $\begin{array}{l}\text { Study design/Number } \\
\text { of participants }\end{array}$ & Results: illness/risks & $\begin{array}{l}\text { Strobe } \\
\text { Score }\end{array}$ \\
\hline $\begin{array}{l}\text { Latency periods in asbestos-related } \\
\text { mesothelioma of the pleura }{ }^{(13)}\end{array}$ & $\begin{array}{l}1997 \\
\text { Italy }\end{array}$ & $\begin{array}{l}\text { Cohort } \\
\mathrm{N}=421\end{array}$ & $\begin{array}{l}\text { Pleural mesothelioma/asbestos exposure due to } \\
\text { repair and shipbuilding industries. }\end{array}$ & $76.4 \%$ \\
\hline
\end{tabular}


...continuation

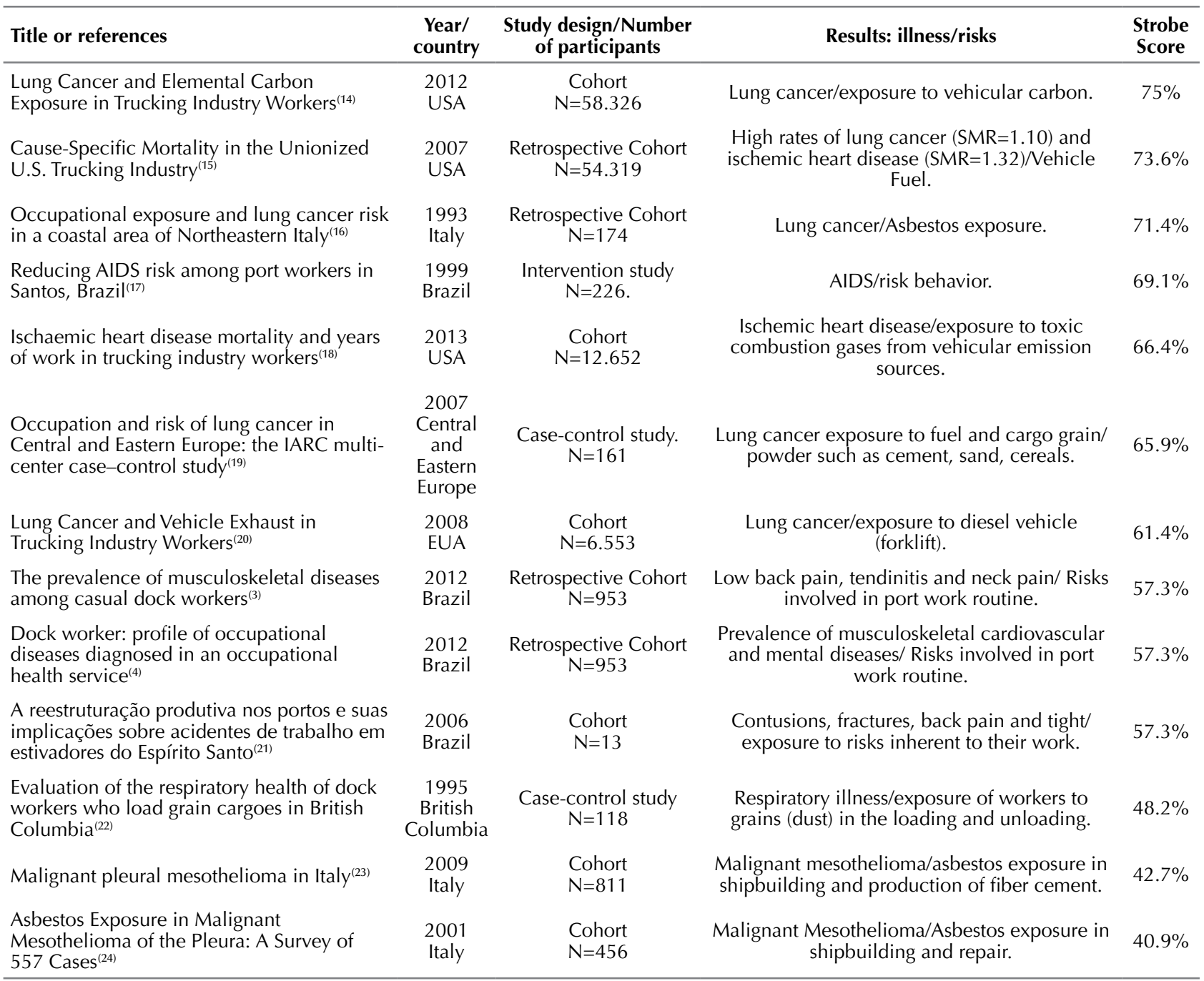

Source: Research data, Rio Grande, 2015.

\section{THE ILLNESSES RELATED TO PORT WORK}

The studies explored the occurrence of work-related cancer $^{(13-16,19-20,23-24)}$. Some investigations were retrospective, with the use of medical records and health service records ${ }^{(14-16,20)}$.

One study ${ }^{(15)}$ showed secondary data on cases of lung cancer and ischemic diseases in an exposure ratio of workers to liquefied propane of trucks circulating in automotive stock areas. It did not show the specific number of ports, but investigated stevedores and other categories of workers of a transport company, noting that those who worked driving the machinery had a higher risk of developing illnesses.

It was also carried out research through health records ${ }^{(16)}$, identifying that 53 dockworkers who worked under the effects of asbestos in shipbuilding, especially during the Second World War, they estimated higher risk for developing lung cancer.

Studies ${ }^{(15-16)}$, also conducted from secondary data, investigated 5,710 dockworkers and 843 conferees at risk for developing lung cancer, given the exposure to diesel vehicles circulating in port terminals. The authors showed that, compared to diesel carcinogenicity, the composition of vehicle fuels such as forklifts has been modified, which mitigated the exposure for each category of workers.

The work in load transportation was analyzed and showed that it presents a risk for lung cancer by exposure to fuels and loads of grain or powder, such as cement, sand and grain $^{(19)}$. However, for 161 dockworkers and cargo handlers, the results of the study did not show statistically significant risk estimates, but call for attention to the fact that these workers were exposed to gasoline and diesel emissions, which account for most carcinogenicity to humans.

In addition to lung cancer, malignant mesotheliomas were identified ${ }^{(23-24)}$ in histological samples with presence of asbestos from the shipbuilding and the production of cement, these activities that were part of the port work in the past. In the first study ${ }^{(23)}, 39$ workers exerted port activities, in the period between 1960 and 1998, they were exposed to large loading and unloading of asbestos, shortening the disease latency time when compared with other workers investigated. In another study ${ }^{(24)}$, it was identified that 17 of the 18 workers investigated had asbestos in lung tissues subjected to autopsy, and for 14 cases of the disease, the latency period was on average, 36.3 years. Other 
researchers, ${ }^{(13)}$ specifically worked the latency period for the occurrence of mesothelioma, also arising from asbestos in a sample with 11 dockworkers, identifying 35.4 years as the latency period for the disease.

Regarding the investigation of ischemic heart disease, a study presented as related risk, the working time exposed to mobile sources/vehicular toxic gas stations ${ }^{(18)}$. According to this study, at least 1 year of work in each functional position increased the risk of developing ischemic heart disease among 12,652 stevedores and other workers (long haul and delivery drivers) analyzed. The study finally suggested that the longer the exposure time, the greater the probability of developing ischemic diseases ${ }^{(21)}$. Ischemic diseases were also investigated in another study ${ }^{(15)}$, which had, in addition to ischemic heart disease, lung cancer, because of the high incidence rates related to exposure to vehicle exhaust.

Musculoskeletal disorders were presented by listing the illnesses diagnosed in a medical service port unit, which attended 953 workers $^{(3)}$ (low back pain, neck pain and tendinitis) and musculoskeletal illnesses produced by accidents, causing contusions, fractures, back pain and crush $^{(21)}$.

A study analyzed the prevention of human immunodeficiency virus (HIV) among 226 dockworkers, based on risk behaviors that can lead to infection by the virus ${ }^{(17)}$.

A study conducted in British Columbia ${ }^{(22)}$ investigated the damage to respiratory health (cough and sputum, for example) of longshoremen exposed to dust arising from grain in the loading and unloading processes. The authors recorded 118 dockworkers affected by respiratory illness.

From the survey of clinical diagnosis, one study ${ }^{(4)}$ identified 527 types of illnesses which affected 953 dockworkers in a period of 10 years (2000-2009), highlighting, among them, hypertension, musculoskeletal, respiratory and mental illness.

\section{RISKS THAT INDICATE CAUSAL LINK WITH ILLNESSES AMONG} DOCKWORKERS

The causal relationships related to illnesses of the studies presented, most rottenly, chemical hazards. They were related to occupational exposure to vehicle fuel ${ }^{(14-15,18-20)}$, asbestos from the ship and shipbuilding activities ${ }^{(13,16,23-24)}$ and grain dust ${ }^{(19,22)}$.

Although the causal relationship was related to the risks inherent to dock work routine, addressing them as literature and legislation on port work $^{(3-4)}$, and through self-referral of workers ${ }^{(21)}$. In addition, a study showed that sexual behavior of dockworkers is a risk for the development of viral diseases ${ }^{(17)}$.

\section{DISCUSSION}

Scholars of occupational dockworkers health perform Level 4 studies (cohort or case-control), which do not have the same strength of evidence of randomized/controlled studies $^{(8)}$. Therefore, it shows a limitation to the progression of nursing clinical reasoning as it can hinder viewing of clinical possibilities of nursing care in this work context. However, these studies allow them to view worker morbidity aspects and assist in the identification of occupational characteristics that support the creation of specific assistance strategies. Cohort studies allowed to present important illnesses that affect dockworkers and raised the clinical reasoning of the occurrence of each illness, such as lung cancer, cardiovascular and musculoskeletal diseases and work related disorders to the elements such as chemical exposure by cargo handled, by the working instruments used (machinery), and overall risk involved in the performance of port operations. Regarding casecontrol studies, they were not conclusive when trying to associate the illness and the dock work itself, but inserted variables to clinical reasoning consistent with the illness, working time, smoking and exposure to vehicle exhaust as interfering in illness.

Hence, we see that the CR regarding dockworkers' health proved to be linked to environmental issues, which was confirmed both by the relations established in the studies and the scope of international journals in which the studies were published. The environmental issue was also seen in the use of indexing terms for studies, which highlighted keywords and related descriptors such as "asbestos" and "occupational exposure". This strengthens the environmental view of workers' health that should be associated with the clinical perspective of nursing, highlighting this as an area which, in combination with clinical data submitted by workers, facilitate satisfaction of their needs, supporting the thinking and operation of professional $\mathrm{CR}^{(25)}$.

In the dockworker context, understanding the illness meant to ascertain the possible investigated causal links, which represent both personal environmental constraints when it came to the age of the workers and habits such as smoking, as related to work organization, because they are associated to exposure and occupational hazards advised by the Brazilian Ministry of Health ${ }^{(2)}$. The pulmonary illness was identified as the most frequent occupational lung cancer and mesothelioma, whose causal links were mainly carried out with chemical risks as environmental agents asbestos and carrier gases from cargo or the atmosphere of the port where dock workers perform activities.

Occupational cancer dates from 1775, when cases of the disease were identified in the scrotum of chimney sweeps, as a result of exposure to soot ${ }^{(26)}$. According to the International Labour Organization (ILO), the concentrations of carcinogens substances are higher in workplaces than in other environments, which increases cancer morbidity related to work. The oncogenesis, then, is activated by environmental agents (exogenous) that work on specific genes, triggering the decelerated growth of cells and producing tumors ${ }^{(26)}$.

Exposure to asbestos among dockworkers has often been studied and especially retrospectively, that is, present in construction activities and ship repair carried out by dockworkers in the past, as in the period of World War II, when the material was widely used in vessels for its strength and its low cost ${ }^{(26)}$. This example was brought in a study that showed the Port of Trieste, Italy ${ }^{(23)}$, in which there was also a lot of loading and unloading of asbestos, which induces 
harmful exposure of the worker. In the case of pleural mesothelioma, the disease can be malignant or benign, and arises in the coating layer of the pleural, pericardial or peritoneal cavities. Its causal link with exposure to asbestos was established in 1960 and in the following decade, it was identified also the possibility of domestic contamination, the workers' clothes with the fibers of the substance ${ }^{(2,26)}$. This is essentially an occupational neoplasm, wherein from 70 to $95 \%$ of those who develop this disease have been occupationally exposed to asbestos, triggering the production of lung lesions and other organs, with a latency period between 30 or 50 years $^{(2,26)}$.

Since 2009, the use of asbestos is prohibited, as required by ordinance 1644 , however, the illness due to exposure can still be rising in the coming decades due to improved diagnosis and the long latency time between exposure and disease $\mathrm{e}^{(26-27)}$. Thus, we need to know the past history of occupational workers and the substances they handled, in order to provide early detection of disease and the resources for action/assistance necessary already being provided and invested. Developing preventive measures against these agents is a complex task because of the constant change in the composition of these substances, which makes difficult the clarification of its carcinogenicity, helping to increase the incidence of the disease ${ }^{(26)}$. In addition, it is emphasized that the studies obtained focused on the continuous exposure of the dockworkers to asbestos is considered the main element of exposure and illness for occupational cancer.

In this context, studies show the nursing CR in interventions for the provision of health information related to the disease, the symptoms at the start of oncological treatment and return the worker to routine ${ }^{(28-29)}$. Besides that, there are non-drug alternatives to assist in the return of work activities ${ }^{(30)}$. It is noteworthy, however, that the nursing studies have been developed on the basis of other causal relationships, such as cosmetics, agrochemicals, causing other cancers, such as colorectal and breast, different chemical exposure with respect to dockworkers.

In the exposure to vehicles exhaust, we highlight in the studies, diesel and organic and elemental carbon. Diesel has been, for many years, among the substances likely carcinogens among humans, being only in 2012 considered carcinogenic by the International Agency for Research on Cancer (IARC) ${ }^{(26)}$. Diesel's exhaust is a complex mixture of substances, whose gas phase include carbon monoxide and nitrogen oxides, gases that involve lung carcinogenesis ${ }^{(31)}$.

This emission has been reported among older diesel vehicles $^{(32)}$ and, given the changes brought about by the modernization of port facilities, they can count on more modern equipment, which have more controlled chemical composition of fuels. Still, port structures still have outdated equipment, which cannot provide such arrangements, keeping workers at risk, and it is necessary to emphasize the use of personal and collective protective equipment as one of the preventive measures, mainly because, in port working routine, there is a continuous and prolonged exposure to the recent emission of gases, in other words, the worker acts as the emission takes place.
In addition, the study demonstrates the multifunctionality ${ }^{(4)}$, where activities that require the same qualification can be carried out by skilled workers, regardless of the professional category to which they belong to, taking workers to operate different machines for different working hours and with various forms of exposure, making the health assessment and protection measures difficult. In this reality, a nursing study highlighted the multifunctionality in their own professional category, verifying that the differentiation of the levels of qualification of nurses and nursing staff itself, as well as the types of work and institutions where professionals work as risk factors associated with muscle disorders ${ }^{(33)}$. This demonstrates that the multifunctionality has already been included in the nursing $\mathrm{CR}$ processing in its own category, so, it is necessary to use this process to operate with dockworkers.

Another illness highlighted in the studies were ischemic diseases, which were not specified in the selected studies, but, according to the Brazilian Ministry of Health, it can be acute myocardial infarction and angina ${ }^{(2)}$. Risk factors for the development of diseases in this group are multifactorial and may be related to lifestyle and health of individuals, such as food, alcohol intake, obesity, among others, hindering the causal link. However, in relation to occupational exposure, carbon monoxide from cargo and vehicle emissions causes decreased blood capacity of oxygen transport and tissue oxygen release, which may contribute to ischemic diseases translated in the investigated studies ${ }^{(2)}$. A nursing study verified the need for prevention of coronary disease programs in the workplace by identifying the age and the type of occupation as important predictors of these illnesses among bus and taxi drivers ${ }^{(34)}$. Yet a Korean study showed a reduction in risk for cardiovascular disease among male workers when they had better physical fitness ${ }^{(35)}$, showing an alternative to address the prevention of cardiovascular illness in health programs.

The musculoskeletal disorders were represented by diseases such as low back pain, and changes/lesions in bone structures resulting from work accidents, represented by fractures and contusions. Overall, musculoskeletal illness is portrayed through the Repetitive Strain Injury (RSI) and Musculoskeletal Diseases related to work (MSDs), which constitute illnesses of difficult conceptualization, by its multifactorial nature, making the causal link with the work questioned and clarified over the years, even with the epidemiological and ergonomic evidence ${ }^{(2)}$. As the studies in this review, a research that studied workers of the Port of Santos ${ }^{(36)}$ also identified the painful symptoms of the spine, especially the lower back, which, together with mental disorders, caused sick leave of the subjects. Although this illness has been identified by less research methodologies of low evidence, from 34 existing ports in Brazil, this illness has been detected in three, which raises the investigation of other characteristics that can interfere with pathological involvement and the need for studies with workers from other ports.

Among the studies that showed this illness, one was carried out by nurses, which confirms the CR processing 
for musculoskeletal care, also observed in nursing workers and other professional categories in which studied the painful symptomatology, gender and the age of the workers, the organization of work characteristics and smoking ${ }^{(37)}$. It was also checked by applying test and a surveillance tool ${ }^{(38)}$; the work shift and work dynamics ${ }^{(39)}$, among others, demonstrating that nursing has already promoted theoretical and methodological instrumentation for musculoskeletal diseases, and already points important elements for CR processing in the port environment.

It is believed that this review presents new research objects that progress in nursing CR process, contributing to the improvement of health care for the dockworkers and other professional categories. In addition to the illnesses, we detected the risks as important causal links for the processing of reasoning, which require knowledge of the work process, both retrospective as current, personal and environmental work for the instrumentalization of professional action.

\section{CONCLUSION}

Occupational lung cancer, ischemic disorders and musculoskeletal disorders were the most frequently researched diseases in dockworkers' health. The causal links have been identified through chemical risks, by previous exposure to asbestos, and by exposure to atmospheric gases from vehicle exhaust and own cargo handled. As for the causal links to other illnesses, there are general risks affecting dockworkers such as routine, functions, instruments and working hours.

From the study, it was observed that, for the construction of the nursing $\mathrm{CR}$, environmental and instrumental knowledge of port operations should be provided, requiring researchers to learn the elements that are part of daily life and directly influence the illness and history of previous work, seeking information to prevent the development of diseases. Knowledge of environmental conditions must be constant, so that it minimizes the difficulty of establishing causal relationships and to facilitate the plans of nursing clinical actions.

\section{RESUMO}

Objetivo: Identificar evidências científicas de adoecimento ocupacional do trabalhador portuário publicadas na literatura. Método: Revisão sistemática da literatura, construída conforme o método Cochrane. As bases de dados pesquisadas foram Cochrane, LILACS, MEDLINE/PubMed, CINAHL e SciELO. Foram selecionados artigos publicados de 1988 a 2014. Os dados foram analisados conforme o Nível de Evidência e Strengthening the Reporting of Observational Studies in Epidemiology. Resultados: Foram selecionadas 14 publicações, das quais $11(78,6 \%)$ de revistas internacionais. O ano de 2012 reuniu maior número de publicações no período de estudo. Todas as publicações pertenciam ao Nível de Evidência 4, destacando o câncer pulmonar, doenças osteomusculares e isquêmicas, com nexo causal nos riscos químicos. Conclusão: A elaboração de medidas preventivas deve prever especialmente a exposição química do trabalhador, aplicando ao raciocínio clínico do enfermeiro um conhecimento ambiental para a assistência aos adoecimentos.

\section{DESCRITORES}

Saúde do Trabalhador; Riscos Ocupacionais; Enfermagem do Trabalho; Revisão.

\section{RESUMEN}

Objetivo: Identificar evidencias científicas de enfermización ocupacional del trabajador portuario publicadas en la literatura. Método: Revisión sistemática de la literatura, planteada conforme al método Cochrane. Las bases de datos investigadas fueron Cochrane, LILACS, MEDLINE/PubMed, CINAHL y SciELO. Fueron seleccionados artículos publicados de 1998 a 2014. Los datos fueron analizados conforme al Nivel de Evidencia y Strengthening the Reporting of Observational Studies in Epidemiology. Resultados: Fueron seleccionadas 14 publicaciones, de las que $11(78,6 \%)$ fueron de revistas internacionales. El año del 2012 reunió mayor número de publicaciones en el período de estudio. Todas las publicaciones pertenecían al Nivel de Evidencia 4, destacando el cáncer pulmonar, las enfermedades osteomusculares e isquémicas, con nexo causal en los riesgos químicos. Conclusión: La elaboración de medidas preventivas debe prever especialmente la exposición química del trabajador, aplicando al razonamiento clínico del enfermero un conocimiento ambiental para la asistencia a las enfermizaciones.

DESCRIPTORES

Salud Laboral; Riesgos Laborales; Enfermería del Trabajo; Revisión.

\section{REFERENCES}

1. Carvalho EC, Cruz DA, Herdman TH. Contribuição das linguagens padronizadas para a produção do conhecimento, raciocínio clínico e prática clínica da Enfermagem. Rev Bras Enferm [Internet]. 2013 [citado 2015 nov. 3];66(n.esp):134-41. Disponível em: http://www. scielo.br/pdf/reben/v66nspe/v66nspea17.pdf

2. Brasil. Ministério da Saúde; Organização Pan-Americana da Saúde. Doenças relacionadas ao trabalho: manual de procedimentos para os Serviços de Saúde [Internet]. Brasília; 2001 [citado 2015 nov. 3]. Disponível em: http://bvsms.saude.gov.br/bvs/publicacoes/doencas_ relacionadas_trabalho1.pdf

3. Almeida MCV, Cezar-vaz MR, Soares JF, Silva MR. The prevalence of musculoskeletal diseases among casual dock workers. Rev Latino Am Enfermagem [Internet]. 2012 [cited 2015 Nov 3];20(2):243-50. Available from: http://www.scielo.br/pdf/rlae/v20n2/05.pdf

4. Almeida MCV, Cezar-vaz MR, Rocha LP, Cardoso LS. Dock worker: profile of occupational diseases diagnosed in an occupational health service. Acta Paul Enferm [Internet]. 2012 [cited 2015 Nov 3];25(2):270-6. Available from: http://www2.unifesp.br/acta/pdf/v25/ n2/v25n2a18_en.pdf 
5. Cezar-Vaz MR, Almeida MCV, Bonow CA, Rocha LP, Borges AM, Piexak DR. Casual dock work: profile of diseases and injuries and perception of influence on health. Int J Environ Res Public Health. 2014;11(2):2077-91.

6. Cezar-Vaz MR, Soares JFS, Almeida MC, Cardoso LS, Bonow CA. Doenças relacionadas ao trabalho autorreferidas por trabalhadores portuários avulsos. Ciênc Cuid Saúde. 2010;9(4):774-81.

7. Brasil. Lei n. 12.815, de 5 de junho de 2013. Dispõe sobre a exploração direta e indireta pela União de portos e instalações portuárias e sobre as atividades desempenhadas pelos operadores portuários; altera as Leis n. 5.025, de 10 de junho de 1966, n.10.233, de 5 de junho de 2001, n.10.683, de 28 de maio de 2003, n.9.719, de 27 de novembro de 1998, e 8.213, de 24 de julho de 1991; revoga as Leis n. 8.630, de 25 de fevereiro de 1993, e 11.610, de 12 de dezembro de 2007, e dispositivos das Leis n. 11.314, de 3 de julho de 2006 e 11.518, de 5 de setembro de 2007; e dá outras providências [Internet]. Brasília; 2013 [citado 2015 nov. 3]. Disponível em: http://www. planalto.gov.br/ccivil_03/_ato2011-2014/2013/Lei/L12815.htm

8. Higgins JP, Green S, editors. Cochrane handbook for systematic reviews of interventions. Version 5.1.0 [Internet]. updated March 2011 [cited 2015 Nov 4]; Available from: http://handbook.cochrane.org/

9. Stone PW. Popping the (PICO) question in research and evidence-based practice. Appl Nurs Res. 2002;15(3):197-8.

10. United Kingdom. The Docks Regulations 1988. Health and safety. Statutory Instruments 1988, n. 1655 [Internet]. Norwich; 1988 [cited 2015 Nov 4]. Available from: http://www.legislation.gov.uk/uksi/1988/1655/introduction/made

11. Stillwell SB, Fineout-Overholt E, Melnyk BM, Williamson KM. Searching for the evidence strategies to help you conduct a successful search. Am J Nurs. 2010;110(5):41-7.

12. Brasil. Lei n. 9.610, de 19 de fevereiro de 1998. Altera, atualiza e consolida a legislação sobre direitos autorais e dá outras providências [Internet]. Brasília; 1998 [citado 2015 nov. 3]. Disponível em: http://www.planalto.gov.br/ccivil_03/leis/L9610.htm

13. Bianchi C, Giarelli L, Grandi G, Brollo A, Ramani L, Zuch C. Latency periods in asbestos-related mesothelioma of the pleura. Eur J Cancer Prev. 1997;6(2):162-6.

14. Garshick E, Laden F, Hart JE, Davis ME, Eisen EA, Smith TJ. Lung cancer and elemental carbon exposure in trucking industry workers. Environ Health Perspect. 2012;120(9):1301-6.

15. Laden F, Hart JE, Smith TJ, Davis ME, Garshick E. Cause-specific mortality in the unionized U.S. trucking industry. Environ Health Perspect. 2007;115(8):1192-6.

16. Bovenzi M, Stanta G, Antiga G, Peruzzo P, Cavallieri F. Occupational exposure and lung cancer risk in a coastal area of Northeastern Italy. Int Arch Occup Environ Health. 1993;65(1):35-41.

17. Hearst N, Lacerda R, Gravato N, Hudes ES, Stall R. Reducing AIDS risk among port workers in Santos, Brazil. Am J Public Health. 1999;89(1):76-8.

18. Hart JE, Garshick E, Smith TJ, Davis ME, Laden F. Ischaemic heart disease mortality and years of work in trucking industry workers. Occup Environ Med. 2013;70(8):523-8.

19. Bardin-Mikolajczak A, Lissowska J, Zaridze D, Szeszenia-Dabrowska N, Rudnai P, Fabianova E, et al. Occupation and risk of lung cancer in Central and Eastern Europe: the IARC multi-center case-control study. Cancer Causes Control. 2007;18(6):645-54.

20. Garshick E, Laden F, Hart JE, Rosner B, Davis ME, Eisen EA, et al. Lung cancer and vehicle exhaust in trucking industry workers. Environ Health Perspect. 2008;116(10):1327-32.

21. Bourguignon DR, Borges LH. A reestruturação produtiva nos portos e suas implicações sobre acidentes de trabalho em estivadores do Espírito Santo. Cad Saúde Colet. 2006;14(1):63-80.

22. Dimich-Ward HD, Kennedy SM, Dittrick MA, DyBuncio A, Chan-Yeung M. Evaluation of the respiratory health of dock workers who load grain cargoes in British Columbia. Occup Environ Med. 1995;52(4):273-8.

23. Bianchi C, Bianchi T. Malignant pleural mesothelioma in Italy. Indian J Occup Environ Med. 2009;13(2):80-3.

24. Bianchi C, Brollo A, Ramani L, Bianchi T, Giarelli L. Asbestos exposure in malignant mesothelioma of the pleura: a survey of 557 cases. Ind Health. 2001;39(2):161-7.

25. Oliveira DC, Vidal CR, Silveira LC, Silva LM. O processo de trabalho e a clínica na enfermagem: pensando novas possibilidades. Rev Enferm UERJ. 2009;17(4):521-6.

26. Instituto Nacional de Câncer José Alencar Gomes da Silva (INCA). Diretrizes para a vigilância do câncer relacionado ao trabalho [Internet]. Rio de Janeiro: INCA; 2012 [citado 2015 nov. 3]. Disponível em: http://bvsms.saude.gov.br/bvs/publicacoes/inca/diretrizes_vigilancia_ cancer_trabalho.pdf

27. Brasil. Ministério da Saúde. Portaria n. 1.644, de 20 de julho de 2009. Veda, ao Ministério da Saúde e aos seus órgãos vinculados, a utilização e a aquisição de quaisquer produtos e subprodutos que contenham asbestos/amianto em sua composição, e disciplina demais providências [Internet]. Brasília; 2009 [citado 2015 nov. 3]. Disponível em: http://bvsms.saude.gov.br/bvs/saudelegis/gm/2009/ prt1644_20_07_2009.html

28. Bains M, Munir F, Yarker J, Steward W, Thomas A. Return-to-work guidance and support for colorectal cancer patients: a feasibility study. Cancer Nurs. 2011;34(6):E1-12.

29. Jefford M, Lotfi-Jam K, Baravelli C, Grogan S, Rogers M, Krishnasamy M, et al. Development and pilot testing of a nurse-led posttreatment support package for bowel cancer survivors. Cancer Nurs. 2011;34(3):E1-10.

30. Mourgues C, Gerbaud L, Leger S, Auclair C, Peyrol F, Blanquet M, et al. Positive and cost-effectiveness effect of spa therapy on the resumption of occupational and non-occupational activities in women in breast cancer remission: a French multicentre randomised controlled trial. Eur J Oncol Nurs. 2014;18(5):505-11.

31. Vermeulen R, Silverman DT, Garshick E, Vlaanderen J, Portengen L, Steenland K. Exposure-response estimates for diesel engine exhaust and lung cancer mortality based on data from three occupational cohorts. Environ Health Perspect. 2014;122(2):172-7. 
32. Ueda AC, Tomaz E. Inventário de emissão de fontes veiculares da região metropolitana de campinas, São Paulo. Quim Nova. 2011;34(9):1496-500.

33. Simmons B. Clinical reasoning: concept analysis. J Adv Nurs. 2010;66(5):1151-8.

34. Park K, Hwang SY. 10-year risk for cardiovascular disease among male workers in small-sized industries. J Cardiovasc Nurs. 2015;30(3):267-73.

35. Ka SS, Kim JS, Lee MY, Kim SH, Jeong HC, Lee MK, et al. The link between health-related physical fitness level and cardiovascular diseaserelated risk factors. Korean J Occup Health Nurs. 2014;23(2):97-105.

36. Alencar MC, Biz RA. Relações entre condições e organização do trabalho e os afastamentos de trabalhadores portuários de transporte. Rev Ter Ocup Univ São Paulo. 2012;23(3):208-15.

37. Magnago TS, Lisboa MT, Griep RH, Kirchhof AL, Camponogara S, Nonnenmacher CQ, et al. Condições de trabalho, características sociodemográficas e distúrbios musculoesqueléticos em trabalhadores de enfermagem. Acta Paul Enferm. 2010;23(2):187-93.

38. Petersen RS, Marziale MH. Low back pain characterized by muscle resistance and occupational factors associated with nursing. Rev Latino Am Enfermagem. 2014;22(3):386-93.

39. Trindade LL, Schuh MC, Krein C, Ferraz L, Amestoy SC. Dor osteomusculares em trabalhadores da indústria têxtil e sua relação com o turno de trabalho. Rev Enferm UFSM. 2012;2(1):108-15. 